\title{
Resolving Difficulties of Agriculture-related Small and Micro Enterprises in Applying for Loans
}

\author{
Minchuan Yuan', Jianzhou Yang ${ }^{2}$ \\ ${ }^{1}$ College of Management, Fujian Agriculture and Forestry University, Fuzhou, Fujian Province, China. \\ ${ }^{2}$ College of Economics, Fujian Agriculture and Forestry University, Fuzhou, Fujian Province, China
}

Keywords: commercial banks; agriculture-related enterprises; small and micro enterprises; financial support

\begin{abstract}
The rural revitalization strategy implemented by the state provides a historic opportunity for the new round of agricultural and rural economy development. In the modern agricultural economy, financial support plays an essential role in the development of small and micro enterprises. This paper analyzes the difficulties of agriculture-related small and micro enterprises in applying for loans, as well as the effectiveness of policies and measures issued by relevant state departments. The paper also puts forward some countermeasures and suggestions on how to better promote the development of loan transactions target for agriculture-related small and micro enterprises.
\end{abstract}

\section{Introduction}

Under the background of rural revitalization strategy, a major development opportunity for agriculture and rural economy is coming. Since the 18th National Congress of the CPC, agriculture-related small and micro sized enterprises, which are responsible for agricultural operation and modern agriculture service, have flourished like bamboo shoots after the rain. These enterprises are represented by family farms and farmers' professional cooperatives. They have become an indispensable component in the agricultural industry chain, linked small farmers and modern agricultural development, and promoted the development of rural economy. Their positions cannot be replaced by large and medium sized enterprises, especially in aspects like the improvement of urban and rural market system, the promotion of innovations in agricultural technology, the employment of rural labor, poverty relief, the processing and exportation of agricultural products, as well as the acceleration of new urbanization process. They have become an important engine which promotes the revitalization of rural areas in China. However, in the development process, because of its inherent weakness, agricultural industry usually faces the risks of long production cycles, uncertain incomes and susceptible to the impact of climate. Most of the agricultural-related small and micro enterprises are unable to obtain financial supports from commercial banks, which lead to financial difficulties and shortage of management funds. With the rapid development of modern agriculture, small and micro enterprises related to agriculture urgently need commercial banks to innovate rural financial products and service models, and reform the business process on agricultural credit, in order to provide strong financial supports for the modernization of their production process.

At present, the competition in Chinese financial market is becoming increasingly fierce. Commercial banks, especially agricultural commercial banks, are in urgent need of strategic transformation. Providing more accessible loan service for agriculture related small and micro enterprises is helpful for commercial banks to optimize their credit asset portfolio, improve profit level and enhance core competitiveness. Therefore, financial services target for agriculture related small and micro enterprises should attract the attention of commercial banks.

\section{Present Situation of Credit Financing of Agriculture-related Small and Micro Enterprises}

The first problem is inadequate financing channels. Agriculture related small and micro enterprises are not easy to get loans from commercial banks because they don't have collaterals. 
Meanwhile, their management mode is backward, while their credit standing and respectability are poor. Many small and micro enterprises related to agriculture have strong demands for credit financing in the stage of entrepreneurship and development, but there are not enough financing channels which are suitable for them in the market. Financing difficulty has been plaguing most agriculture related small and micro enterprises. Insufficient funds are the biggest obstacles which hinder the development of small and micro enterprises related to agriculture.

The second problem is high financing cost. Spend money expense and costs of financing have become the prime cost of enterprises. But at present, small and micro enterprises related to agriculture cannot enjoy preferential policies on interest rate when applying for loan. On the contrary, they have to pay more loan interests compared with other types of enterprises, and bear additional conditions required by banks. Therefore, when in need of fast financing, they often choose private lending channels with high financing costs but convenient procedures.

The third problem is imperfect agricultural credit policies. Under the influence of subordinated debts, credit risks, as well as the proportion of bad debts increases greatly. Small and micro enterprises related to agriculture have many shortcomings, such as weak strength, small scale, poor credit record and imperfect credit guarantee system. Although the state has issued policies to expand credit support to small and micro enterprises related to agriculture, from the point of view of risk aversion, commercial banks are more inclined to offer loans to large and medium-sized enterprises with low risks and low credit costs. Their credit supports for agriculture-related small and micro enterprises are very limited.

The fourth problem is the gap between credit policies issued by state and the credit management strategies of commercial banks. In recent years, the state has focused on the special needs of agriculture-related small and micro enterprises on financing, and introduced a series of policies and measures to promote the sustainable and healthy development of these enterprises. But in reality, related laws, regulations and policies are still imperfect; commercial banks have encountered many difficulties and problems in the process of policy implementation. The problem of financing difficulty for agriculture-related small and micro enterprises has not been solved effectively. For example, the low credit rating of most agriculture-related small and micro enterprises does not conform with credit rating standards of commercial banks. Meanwhile, commercial banks are constrained by the target of capital adequacy, and have to compress the proportion of risk assets. It is difficult for them to effectively increase the credit scale for small and micro enterprises related to agriculture.

In addition, although grass-root organizations of commercial banks are close to small and micro enterprises, they have extremely limited rights to approve loans. Because of the limited rights of grass root banks, a number of small and micro enterprises related to agriculture fail to get loans. Some enterprises give up the loan because the cumbersome loan procedures, long examination and approval process, as well as complicated credit links make them lose the market opportunity.

\section{New Financial Policy to Boost Credit Services Target for Agriculture-related Small and Micro Enterprises}

In recent years, in view of the particularity of loans for agriculture-related small and micro enterprises, the state has successively promulgated a series of policies and documents to support the development of these enterprises. These policies include Guidance on Financial Services Target for New Agricultural Management Entities Such as Family Farms, Guidance on Providing Further Financial Services for Small and Micro Enterprises, and Guidance on Supporting Commercial Banks to Further Improve Financial Services Target for Small Enterprises. Measures included in these documents complement each other, and alleviate the loan difficulty of small and micro enterprises related to agriculture to a certain extent. These policies also creates a huge blue ocean for all commercial banks, pointing out their transformation and development path.

Since the new century, with the rise of entrepreneurial boom, various commercial banks have made a variety of exploration and innovation in supporting small and micro enterprises, and thus accumulated valuable service experience. In this process, commercial banks gradually realize that, in 
order to provide good loan services for agriculture related small and micro enterprises, they need to expand in-depth market and explore customers' demand. Meanwhile, they also need to break through obstacles in concept, in order to truly understand the loan business targeted for agriculture-related to small and micro enterprises. They also need to innovate the modes of rural financial products and services, and establish effective rules and regulations to can control risks; a new type of bank-enterprise relationship is also needed since it can bring mutual benefits and common growth.

Therefore, the core problem of providing loan business for agriculture-related small and micro enterprises is that, commercial banks need to change their traditional concepts, and abandon the idea of unwilling to provide loans for these enterprises because of heavy investment, high risk and low profit. They should understand that these enterprises have long service operation cycles and financial sustainability. Commercial banks should clearly realize that the rural financial market has great potential, while agriculture-related small and micro enterprises have vast development prospects, and can become important customers for banks in the future. As long as a reasonable loan incentive and restraint mechanism is designed, and a scientific risk pricing model is implemented, they should try to develop loan services target for agriculture related small and micro enterprises.

In order to improve loan business targeted for agriculture-related small and micro enterprises, various commercial banks establish and improve credit management mechanisms and business development modes. For example, in accordance with the regulatory authorities' requirement on constructing "five special" mechanisms, the Agricultural Bank and Postal Savings Bank set up the Three Rural Issues Finance Department at all levels, and establish an organization system with "top-down vertical management mechanism and professional services". The department is particularly responsible for policy refinement, product innovation, team building, customer surveys, credit management and service upgrading. At the same time, through the trial of "bilateral accounting" rules, the specialized, total cost and full coverage accounting is carried out in the Three Rural Issues Finance Department to continuously promote the sustainable and steady development of loan business provided for agriculture-related small and micro enterprises.

In addition, the financing demands of small and micro sized enterprises are small in quantity, but urgently and frequently needed with quick turnover high cyclical features. The Postal Savings Bank and other institutions simplify credit application materials, optimize credit transaction process and improve credit service efficiency in accordance with the requirements of "no repetitions in materials, processes and operations". Agricultural credit risk control measures are also carried out. These measures further improve the efficiency of banks in serving small and micro enterprise related to agriculture.

\section{Opening up Credit Financing Channels for Agriculture-related Small and Micro Enterprises through Diversified Approaches}

First, banks need to innovative product services to meet differentiated financing requirements. Small and micro enterprises related to agriculture are large in number and wide in scope. Their financial needs are quite different because they are in different industries, scales and development cycles. Therefore, the Postal Savings Bank should focus on the needs of agriculture, rural areas and rural residents, adhere to market orientation, pay close attention to new national rural policies, employ Internet and other new technologies, and constantly develop diversified financial products with agricultural characteristics of agriculture, rural areas and farmers.

The first measure is product innovation. In accordance to the characteristics of agricultural credit, agricultural equipment and facilities, as well as inventory and warehouse receipt can serve as the pledge. Performance guarantee business, agricultural industry chain financing, accounts receivable pledge, franchise rights pledge and agricultural equipment financing lease should also be offered to enterprises. At the same time, banks should actively promote and expand the coverage of mortgage business on rural contracted land management rights, farmers' housing property rights, seine breeding rights and forest rights.

The second measure is service innovation. For example, for small and micro enterprises with high technological content and good market prospects, the access threshold could be lowered. Preferential 
policies like carrying out time limited services and pre services should be implemented. Small and micro enterprises with small business scales and low business risks could be provided with counter service. In the case of effective mortgage, the link of evaluating credit grade could be eliminated; the lending officer can handle the business directly. A "green channel" could be opened to trustworthy agriculture related small and micro enterprises; the credit lines of these enterprises could be approved ahead of schedule.

The third measure is technological innovation. Exploration and application of techniques like large data, intelligent interconnection and cloud computing can enhance customer access, facilitate links of information access, online evaluation, as well as credit examination and approval, and improve the capacity of banks in product innovation, post loan management and credit management. The business operation costs could also be reduced.

Second, specialized bank branches could be established to deal with agriculture related business, and change the established thinking of "from bottom to up" service pattern. In regions with better agricultural industry clusters and modern agricultural industrialization, detailed market research could be carried out together with credit analysis and development planning. By establishing specialized agriculture related branches, banks can create product models, as well as marketing and management modes which can satisfy the credit and financing demand of small and micro enterprises related to agriculture. Cooperation platforms can also be built to provide risk sharing and compensation mechanisms.

Third, the interest rate of agriculture related loans should be optimized. First, banks should formulate the floating model of interest rate according to price policies and the trend of market interest rates, combined with actual situations of capital, tax and operation cost, target profit, as well as the overall risk control situation and the quality of assets. Second, on the basis of above valuation model, the coefficient should be adjusted according to customers' qualifications, credit rates, comprehensive contribution degrees, guarantee methods, loan terms, credit amounts, as well as their scientific and technological levels and the development prospects of industry. Third, a differential pricing method should be taken according to customers' risk levels.

Fourth, the credit evaluation index system target for agriculture related small and micro enterprises should be optimized. In addition to investigating the development potentials of small and micro enterprises, the prospects of their products, the comprehensive qualities and management levels of enterprises, as well as their net assets and status of credit, the investigation and analysis on "three products and three forms" should also be emphasized. The set point of credit rating index model could be appropriately adjusted. At the same time, banks should increase the credit enhancement effect of second repayment sources, so as to provide reliable references for credit supply and risk control.

Fifth, the credit performance assessment measures should be improved.

The first method is to establish an incentive assessment mechanism of profit and risk sharing. Linking the income of credit officers to their comprehensive performances, such as business volume, working efficiency and loan quality, can improve their enthusiasm in business development. For example, in the whole business process, credit members, examination and approval personnel and other related employees can share the credit profits in proportion. Loan volumes should be considered in their performance assessment. At the same time, a certain degree of risk tolerance should be offered. For the amount of loan loss which exceeds the limit of risk tolerance, the performance bonus should be withdrawn in proportion; if the loan is repaid, the performance bonus could be returned in accordance with the time and amount of repayment.

The second method is to strengthen risk management ability related to agriculture credit. For loan losses caused by irresistible forces like market risk and credit risk, once checked and verified, the responsibility of operators should be allayed or exempted. For loan professionals who fail to fulfill their obligations like credit review and risk control, punishment and position transfer should be carried out. For non-performing loans caused by subjective reasons, the operator should be punished according to internal and external rules and regulations. If the situation is serious, the case should be transferred to judicial organs according to the law; their legal responsibilities should be investigated.

The third method is to provide greater tolerance to non-performing loans of small and micro 
businesses related to agriculture. Within the tolerance, no restraint measures should be adopted to punish bank employees who are responsible for agricultural credit management. At the same time, the principle of "fulfill duty and liability exemption" should be strictly implemented to reduce the concerns of employees, and fully mobilize their initiative in marketing agricultural loan business.

\section{Acknowledgement}

Fund Project: This paper is one of the outcomes of the research, Study on the Optimization of Green Credit System in Fujian Province, which is supported by Foundation for Key Projects of Fujian Federal of Social Science Circles (Project No:. 2016JDZ042).

\section{References}

[1] D.H. Fu, Low cost solution to difficulty of loaning for small and medium-sized enterprise related to agriculture, J. China finance. 16 (2012).

[2] G.J. Wei, Take the road of characteristic bank development: Interview with Jia-jin Lv, President of Postal Savings Bank of China, J. China Finance. 5 (2015).

[3] M.C. Yuan, Exploring the road of distinctive development of small business loans, J. China Post. 10 (2011).

[4] M.C. Yuan, T.T. Shang, Transformation of postal savings bank in the era of Internet finance, J. Studies on Posts. 3 (2015). 